\title{
Changes in soil properties and plant biomass under the influence of soda waste ponds in Inowrocław, Poland
}

\author{
*Joanna Strzelecka, *Michał Dąbrowski, *Piotr Hulisz, **Agnieszka Piernik \\ *Department of Soil Science, Institute of Geography, Nicolaus Copernicus University, \\ Gagarina 9, 87-100 Toruń, Poland \\ e-mail:sjoanna@doktorant.umk.pl \\ **Laboratory of Ecological Modelling, Institute of Ecology and Environment Protection, \\ Nicolaus Copernicus University, Gagarina 9, 87-100 Toruń, Poland
}

\begin{abstract}
Summary. Nowadays, the waste ponds of the Inowrocław Chemical Plants "Soda-Mątwy" SA are not used for regular disposal of pollutant materials. Despite this, the salinity level of groundwater and soils in the neighbourhood of these ponds is still very high. The main reasons of this are the huge amount of waste stored for decades and very unfavourable location of this factory in the river valley. In the salty area there are saline meadows with halophytes such as: Salicornia europaea, Glaux maritima, Triglochin maritima, Aster tripolium, Puccinellia distans, Atriplex hastata var. salina and Spergularia salina.
\end{abstract}

Key words: industrisols, halophytes, soda industry, soil salinity.

\section{Introduction}

In the all ecosystems the balance between abiotic and biotic environmental components is extremely important. Any disturbance of this balance can cause changes in the relations between the various elements of the environment. In the past, the activity of the Inowrocław Chemical Plants "Soda-Mątwy" SA had significant influence on transformations of the local environment (Cieśla et. al 1981; Hulisz 2003). The long-term deposition of strongly saline, semi-fluid waste products in the sedimentary ponds, situated directly on permeable grounds without proper sealing, caused strong groundwater pollution. As a result, very fertile soils were degraded in the area of over 100 ha. The aim of this study was to analyze the temporal and spatial changes in the properties of groundwater, soils and plant biomass in the surroundings of waste ponds.

\section{The study area}

The waste ponds cover an area over 130 ha. They are located in the valley of the Noteć river, in the southern part of Inowrocław town (Fig. 1). Under the pressure of stored waste the groundwater flow has been changed. The groundwater table became very shallow, $50-100 \mathrm{~cm}$ below surface level. The dominant soil unit is Mollic Gleysols.

\section{Research methods}

The study was conducted at three dates: 21 October 2006 (I), 27 October 2007 (II) and 23 June 2010 (III). The area of about 1 ha, located in the small depression, was selected. Soil, plant and water samples were taken along the transect (Fig. 1). Some properties of soil saturation extract such as electrical conductivity $\left(\mathrm{EC}_{\mathrm{e}}\right)$ and chloride content 


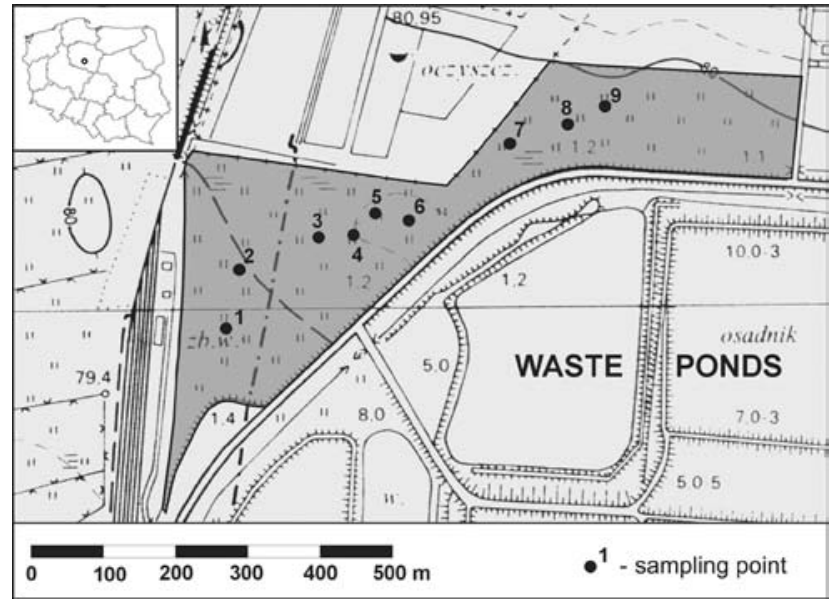

Figure 1. Location of the study area and sampling points were determined (van Reeuwijk 2002). At the third date (III), bulk electrical conductivity $\left(\mathrm{EC}_{\mathrm{a}}\right.$ ) was measured in soil surface horizons $(0-10 \mathrm{~cm})$ by TDR method and the salinity map of the study area was drawn (Surfer 8.0 programme). The vegetation samples were collected on area $25 \times 25 \mathrm{~cm}$ in three replicates. All plants were cut at the soil level and stored in plastic bags. In the laboratory each sample was divided into species, dried at $85^{\circ} \mathrm{C}$ and weighted. For each sampling point the mean total vegetation biomass and mean Salicornia europaea biomass were calculated. The biomass was correlated to the salinity level expressed as chloride concentration.

\section{Results and discussion}

The changes of soil habitat conditions in the study area led to the expansion of halophytes (Wilkon-Michalska 1963; Piernik et. al 1996). The salinity of groundwater was extremely high (I - EC $63 \mathrm{dS} \cdot \mathrm{m}^{-1}, \mathrm{Cl}^{-} 43 \mathrm{~g} \cdot \mathrm{dm}^{-3}$; II - EC $75 \mathrm{dS} \cdot \mathrm{m}^{-1}, \mathrm{Cl}^{-} 51 \mathrm{~g} \cdot \mathrm{dm}^{-3}$ ). As shown in other papers (Cieśla et. al 1981; Hulisz 2003), it was similar in the past.

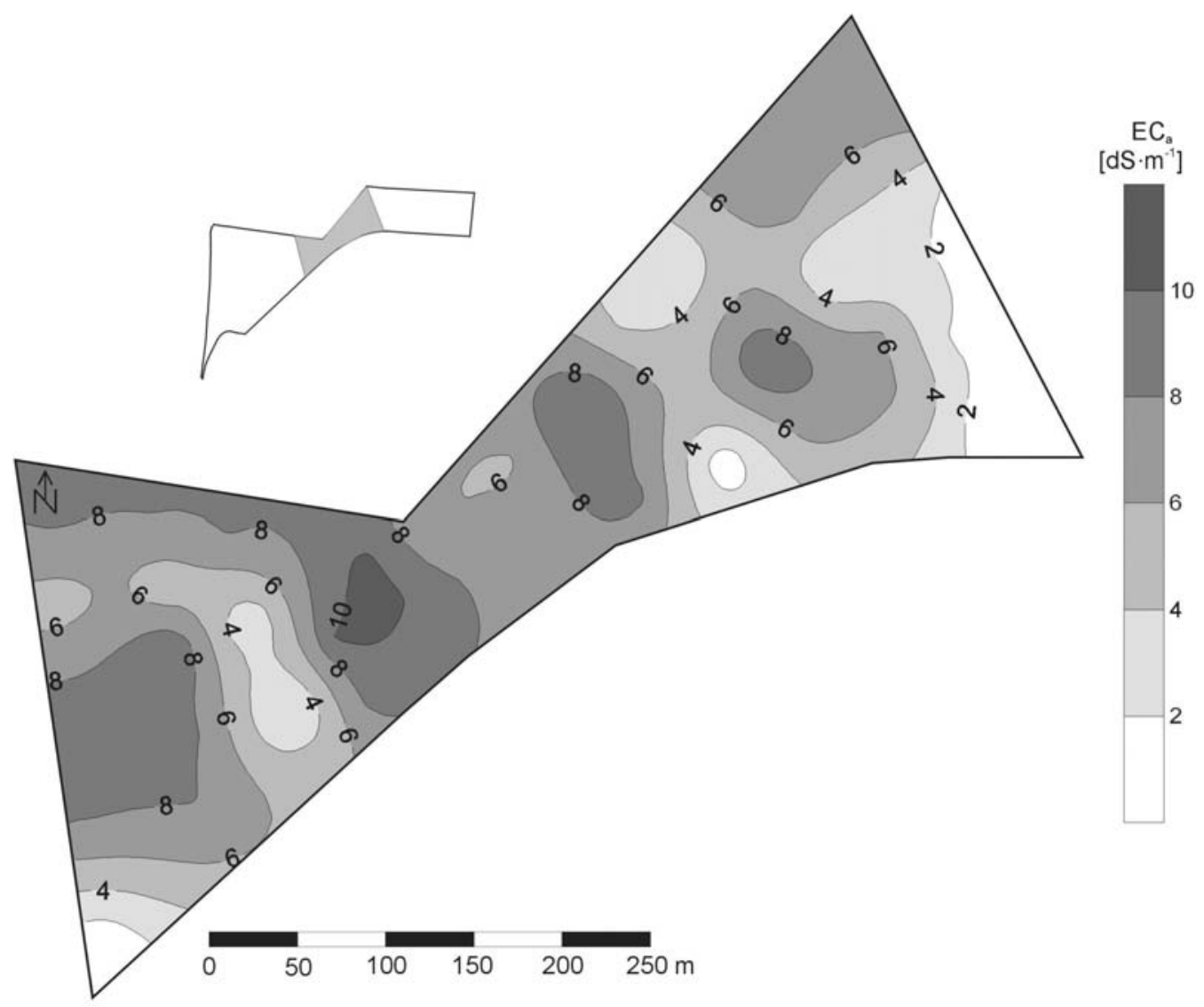

Figure 2. Map of bulk soil electrical conductivity $\left[\mathrm{EC}_{\mathrm{a}}\right]$ measured in $0-10 \mathrm{~cm}$ layer by TDR method (2009) 

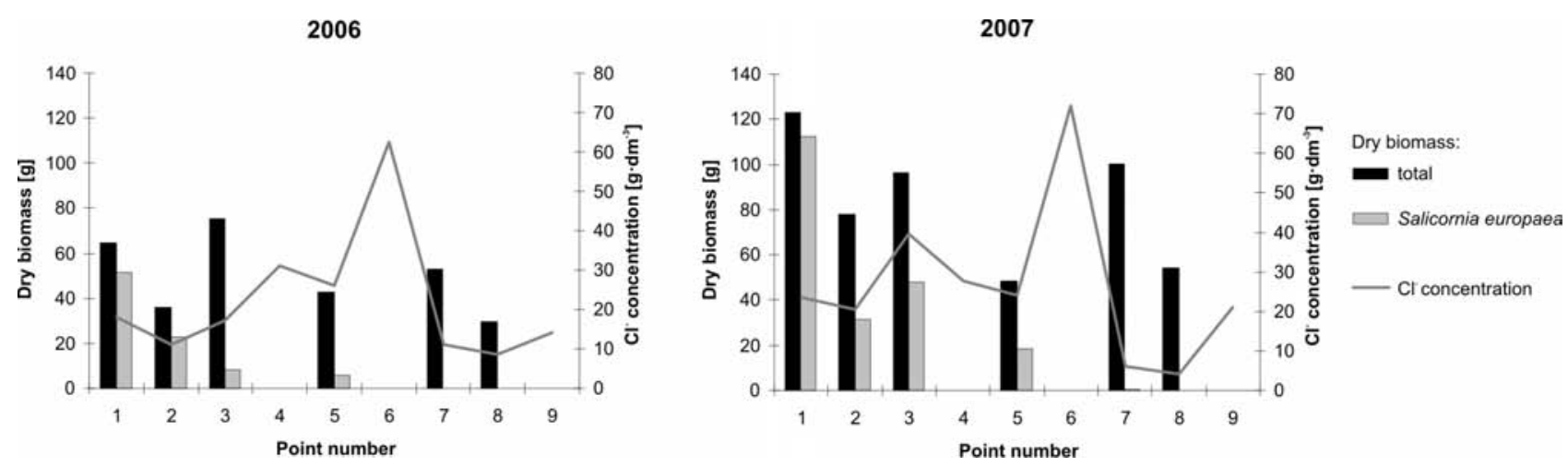

Figure 3. Relationship between dry biomass and the concentration of chlorides (2006 and 2007)

The spatial variability of EC was very high and it corresponded to the microrelief (Fig. 2). The highest salinity $\left(\mathrm{EC}_{\mathrm{a}}>10 \mathrm{dS} \cdot \mathrm{m}^{-1,} \mathrm{EC}_{\mathrm{e}}>80 \mathrm{dS} \cdot \mathrm{m}^{-1}\right)$ occurred in the center of the depression. This part was characterized by complete lack of vegetation. However, in general, as the distance from this place and rise of the terrain, the decrease in EC values was observed. This specific pattern of soil salinity variation was also observed by Pokojska et al. (1998). According Piernik et. al (1996) this factor has affected the development of halophyte zonation.

There were no significant relation between above ground plant biomass and soil salinity level (Fig. 3) as salinity was measured only once in each investigated year. In the humid climate of Poland salinity level is very changeable - lower after rains and few times bigger during the dry periods of summer. The ability for plants to enter salt marsh area is related to the time the meadow is flooded during the spring and to salinity level which allow to germinate in this period. Therefore the biomass level in the certain point is depended not only on salinity level but also on colonization success of certain species during the spring. Some of them i.e. Spergularia salina reach smaller biomass than others i.e. Salicornia europaea.

\section{References}

Cieśla W., Dąbkowska-Naskręt H. \& Siuda W., 1981, Stan zasolenia gleb w okolicy Inowrocławskich Zakładów Chemicznych w Mątwach [Soil salinity state in the neighborhood of the Inowrocław Chemical Plant in Mątwy], Roczn. Gleb. 32 (2): 103-113.

Hulisz P., 2003, Soil salinity in the vicinity of Inowrocław (Poland) due to the effect of soda industry, Abstracts, SUITMA Conference, Nancy: 159-160.

Piernik A., 2003, Inland halophilous vegetation as indicator of soil salinity, Basic Appl. Ecol. 4: 525-536.

Piernik A., Kaźmierczak E. \& Rutkowski L., 1996, Differentiation of vegetation in a saline grassland in the vicinity of Inowrocław Soda Plants at Mątwy, Acta Soc. Bot. Pol. 65 (3-4): 349-356.

Pokojska U., Bednarek R. \& Hulisz P., 1998, Problemy systematyki gleb zasolonych w odniesieniu do obszaru objętego wpływem IZCH „Soda-Mątwy SA” [Taxonomy problems of salt-affected soils with reference to the area influenced by IZCH ,Soda-Mątwy SA”], Zesz. Probl. Post. Nauk Roln. 460: 513-521.

van Reeuwijk L. P., 2002, Procedures for soil analysis, ISRIC, FAO, sixth edition, Wageningen.

Wilkoń-Michalska J., 1963, Halofity Kujaw [Halophytes of Cuiavian region], Stud. Soc. Sc. Tor., Torun. 